\begin{tabular}{c} 
JURNAL REKAYASA PROSES \\
Research article /Vol. 12, No. 2, 2018, hlm. 68-76 \\
Journal homepage: http://journal.ugm.ac.id/jrekpros \\
\hline
\end{tabular}

\title{
Perbandingan Kinerja Penyetelan Hagglund-Astorm dan Tyreus- Luyben pada Sistem Kendali Pendinginan Susu
}

\author{
Rudy Agustriyanto*, Anastasia Febriyanto dan Putu Sri Widiawati \\ Jurusan Teknik Kimia, Fakultas Teknik, Universitas Surabaya \\ Jl. Raya Kali Rungkut No.56, Rungkut, Surabaya 60293 \\ *Alamat korespondensi: rudy.agustriyanto@staff.ubaya.ac.id
}

(Submisi: 20 Agustus 2018; Revisi: 28 September 2018; Penerimaan: 30 September 2018)

\begin{abstract}
A B S T R A C T
Milk cooling process is one of the most important milk processing steps after milk extraction process. Milk cooling process is carried out to inhibit the microbial growth. The milk is cooled from room temperature to $4{ }^{\circ} \mathrm{C}$. Generally, this process is performed in batch installation. In this research, continuous milk cooling would be simulated. First, the model of the system was derived from the mass and heat balance. The simulation results were then identified using the System Identification Toolbox (SIT) on Matlab. System Identification Toolbox was used to build the mathematical models of dynamic system based on measured input and output data. The result of system identification is useful for setting control and stability analysis. The milk cooling system was then controlled by Proportional Integral (PI) Control. There are two kinds of tuning methods that will be analyzed. These are Hagglund-Astorm method and Tyreus-Luyben. The results showed that the control performance tuned using the Tyreus-Luyben method was better than the Hagglund-Astorm method from the criteria of its SSE (sum squared of error).
\end{abstract}

Keywords: control; proportional integral; system identification; tuning.

\section{A B S T R A K}

Proses pengolahan susu yang sangat penting setelah pemerahan adalah proses pendinginan. Proses pendinginan susu digunakan untuk menghambat perkembangbiakan mikrobia. Susu didinginkan dari suhu kamar sampai $4{ }^{\circ} \mathrm{C}$. Umumnya proses ini dilakukan secara batch pada instalasi di koperasi susu. Dalam penelitian ini, disimulasikan sistem pengendalian suhu susu secara kontinu. Model sistem diperoleh dari penurunan neraca massa dan panas. Hasil simulasi kemudian diidentifikasi dengan menggunakan System Identification Toolbox pada Matlab. System Identification Toolbox digunakan untuk menyusun model matematis dari sistem dinamis berdasarkan data input dan output yang diukur. Hasil identifikasi sistem berguna untuk penyetelan pengendali maupun analisis kestabilan. Sistem pendinginan susu kemudian dikendalikan dengan Proportional Intergral (PI) Control. Metode penyetelan yang dianalisis ada dua macam yaitu metode Hagglund-Astorm dan metode TyreusLuyben. Hasil yang diperoleh menunjukkan bahwa kinerja pengendali yang disetel menggunakan metode Tyreus-Luyben lebih baik dibandingkan dengan metode Hagglund-Astorm dilihat dari kriteria SSE nya.

Kata kunci: identifikasi sistem; pengendalian; proportional integral; tuning 


\section{Pendahuluan}

Susu merupakan sumber nutrisi yang baik bagi manusia. Namun di lain pihak, susu merupakan media yang baik bagi pertumbuhan mikroorganisme, terutama bakteri patogen seperti Staphylococcus aureus, Escherichia coli, dan Salmonella sp (Suwito, 2009). Mikroorganisme pada susu mentah dapat berkembang jika disimpan pada suhu tertentu. Mikroorganisme ini akan berbahaya bila dikonsumsi, sehingga susu mentah yang telah diperah harus segera disimpan pada suhu tertentu. Hal ini bertujuan untuk menghambat pertumbuhan mikroorganisme yang dapat menurunkan kualitas susu segar (Ruangwittayanusorn dkk. 2016).

Susu merupakan salah satu bahan pangan yang sangat cepat mengalami penurunan mutu gizi dan mutu sensori apabila tidak mendapat penanganan yang tepat. Penanganan penyimpanan susu setelah diperah dapat dilakukan dengan cara menyimpan pada kondisi suhu rendah yaitu $4{ }^{\circ} \mathrm{C}$. Proses penyimpanan susu pada kondisi suhu rendah dikenal dengan istilah proses pendinginan susu. Pada umumnya, proses pendinginan susu di industri adalah menggunakan air sebagai media pendingin (Murphy dkk., 2012). Media pendingin ini perlu dipasang pengendali untuk memastikan suhu susu yang keluar $4{ }^{\circ} \mathrm{C}$ (Toledo dkk., 2015).

Saat ini, kebutuhan akan produk susu semakin meningkat sehingga industri pengolahan susu segar harus meningkatkan kapasitas produksi sesuai permintaan konsumen. Proses pendinginan secara batch sebaiknya tidak lagi digunakan karena kapasitas susu yang dapat didinginkan kurang besar. Oleh karena itu proses pendinginan susu dapat beralih ke sistem kontinu karena kapasitas susu yang didinginkan dapat lebih banyak. Tentu saja hal ini harus diimbangi dengan peningkatan populasi sapi perah di daerah tersebut.

Tujuan dari penelitian ini adalah membuat simulasi atau simulator sistem pendinginan susu, mengidentifikasi sistem pendinginan susu, dan membandingkan kinerja penyetelan pengendali menggunakan metode Tyreus-Luyben dan Hagglund-Astorm.

\section{Metode Penelitian}

Berikut adalah prosedur yang dilakukan untuk menjalankan penelitian ini:

1. Penentuan sistem yang ditinjau

Sistem yang ditinjau adalah tangki susu yang beroperasi secara kontinu. Tangki susu tersusun atas dua bagian yaitu tangki penampungan susu dan tangki air pendingin seperti tampak pada Gambar 1.

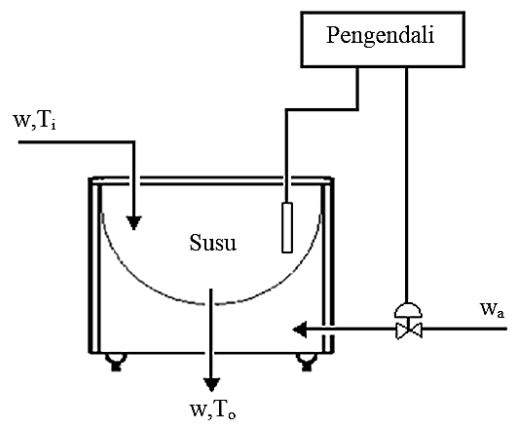

Gambar 1. Skema tangki pendinginan sistem kontinu pada KUD SAE Pujon

2. Penyusunan model matematis

Diasumsikan bahwa volume susu atau massa susu di dalam tangki adalah konstan sehingga neraca massa dapat diabaikan. Model akan diperoleh dari penurunan neraca energi.

Neraca energi unsteady state disajikan dalam Persamaan (1).

$$
\begin{aligned}
& \text { In }- \text { Out }=\text { Acc } \\
& Q_{\text {in }}-Q_{\text {out }}=A c c \\
& w \cdot C_{p} \cdot\left(T_{i}-T_{O}\right)-Q=m \cdot C_{p} \frac{d T_{O}}{d t}
\end{aligned}
$$

Linearisasi $W . T_{i}$ dan $W . T_{o}$ :

$w \cdot T_{i}=w_{s} \cdot T_{i, s}+w_{s} \cdot\left(T_{i}-T_{i, S}\right)+T_{i, s} \cdot\left(w-w_{s}\right)$
$w \cdot T_{O}=w_{S} \cdot T_{O, S}+w_{S} \cdot\left(T_{O}-T_{O, S}\right)+T_{O, S} \cdot\left(w-w_{S}\right)$

Tanda $s$, berarti pada saat steady state.

Persamaan (2) dan (3) ke (1), menjadi:

$\left[\left(T_{i, S}-T_{O, S}\right) \cdot\left(w-w_{S}\right)+w_{S} \cdot\left(T_{i}-T_{0}\right)\right] \cdot C_{p}-Q=m \cdot C_{p} \frac{d T_{0}}{d t}$

Neraca energi steady state dinyatakan dalam Persamaan (5).

$w_{S} \cdot C_{p} \cdot\left(T_{i, s}-T_{o, s}\right)-Q_{S}=0$ 
Substitusi Persamaan (4) dengan Persamaan (5) menghasilkan Persamaan (6).

$\left[\left(T_{i, S}-T_{O, S}\right) \cdot\left(w-w_{S}\right)+w_{S} \cdot\left(\left(T_{i}-T_{i, S}\right)-\left(T_{O}-T_{O, S}\right)\right)\right] \cdot C_{p}-\left(Q-Q_{S}\right)=m \cdot C_{p} \frac{d T_{O}}{d t}$

Transformasi Laplace pada Persamaan (6) menghasilkan Persamaan (7).

$\left\lfloor\left(T_{i, s}-T_{O, S}\right) \cdot W(s)+w_{S} \cdot\left(T_{i}(s)-T_{O}(s)\right)\right\rfloor \cdot C_{p}-Q(s)=m \cdot C_{p}\left(s \cdot T_{O}(s)-T_{O}(o)\right)$

maka dengan $T_{o}(0)=0$, Persamaan (7) dapat dijabarkan lebih lanjut sebagai berikut::

$$
\begin{aligned}
& \left\lfloor\left(T_{i, s}-T_{O, S}\right) \cdot W(s)+w_{s} \cdot\left(T_{i}(s)-T_{O}(s)\right)\right] \cdot C_{p}-Q(s)=m \cdot C_{p} \cdot s \cdot T_{O}(s) \\
& \left(T_{i, S}-T_{O, s}\right) \cdot C_{p} \cdot W(s)+w_{S} \cdot C_{p} \cdot T_{i}(s)-Q(s)=m \cdot C_{p} \cdot s \cdot T_{O}(s)+w_{s} \cdot C_{p} \cdot T_{O}(s) \\
& \left(T_{i, s}-T_{O, S}\right) \cdot C_{p} \cdot W(s)+w_{s} \cdot C_{p} \cdot T_{i}(s)-Q(s)=\left(m \cdot C_{p} \cdot s+w_{s} \cdot C_{p}\right) \cdot T_{O}(s) \\
& T_{O}(s)=\frac{\left(T_{i, s}-T_{O, S}\right) \cdot C_{p} \cdot W(s)+w_{s} \cdot C_{p} \cdot T_{i}(s)-Q(s)}{\left(m \cdot C_{p} \cdot s+w_{s} \cdot C_{p}\right)} \\
& T_{o}(s)=\frac{T_{i}(s)}{\left(\frac{m}{w_{s}} \cdot s+1\right)}-\frac{Q(s)}{\left(\frac{m}{w_{s} \cdot C_{p}} \cdot s+1\right)}-\frac{\left(T_{O, s}-T_{i, s}\right) \cdot W(s)}{\left(\frac{m}{w_{s}} \cdot s+1\right)} \\
& T_{O}(s)=\frac{1}{(\tau \cdot s+1)} T_{i}(s)-\frac{K_{1}}{(\tau \cdot s+1)} Q(s)-\frac{K_{2}}{(\tau \cdot s+1)} W_{S}(s)
\end{aligned}
$$

dengan:

$$
K_{1}=\frac{1}{w_{S} \cdot C} \quad K_{2}=\frac{\left(\mathrm{T}_{\mathrm{o}, \mathrm{s}}-\mathrm{T}_{\mathrm{i}, \mathrm{s}}\right)}{\mathrm{w}_{\mathrm{s}}} \quad \tau=\frac{m}{w_{s}}
$$

maka:

$$
T_{0}(s)=\frac{1}{\left(\frac{m}{w_{s}} \cdot s+1\right)} T_{i}(s)-\frac{K_{1}}{\left(\frac{m}{w_{s}} \cdot s+1\right)} Q(s)-\frac{K_{2}}{\left(\frac{m}{w_{s}} \cdot s+1\right)} W(s)
$$

Keterangan :

$W_{s}$ = Laju alir susu masuk ( $\left.\mathrm{kg} / \mathrm{menit}\right)$

$T_{o, s}=$ Suhu susu masuk saat steady state $\left({ }^{\circ} \mathrm{C}\right)$

$T_{i, s}=$ Suhu susu keluar saat steady state $\left({ }^{\circ} \mathrm{C}\right)$

$m \quad$ = Massa susu masuk $(\mathrm{kg})$ 
3. Simulasi proses dengan menggunakan Simulink.

4. Analisis hasil menggunakan System Identification Toolbox (SIT).

5. Simulasi sistem lintas tertutup.

6. Penyetelan parameter pengendali.

Sistem ini menggunakan pengendali Proportional-Integral (PI). Persamaan kontrol PI dalam bentuk Laplace (Sheng Pai dkk., 2009) :

$$
G_{C}(s)=K c\left(1+\frac{1}{\tau_{i} s}\right)
$$

Untuk memperoleh nilai $K c$ (gain pengendali) dan $\tau_{i}$ (integral time pada pengendali) digunakan metode Tyreus-Luyben dan Hagglund-Astorm.

\section{Metode Tyreus-Luyben}

Penentuan harga parameter PI pada metode ini digunakan persamaan seperti ditunjukkan pada Tabel 1 (Sharokhi, 2008).

Tabel 1. Rumus pengendali PI untuk metode TyreusLuyben

\begin{tabular}{lll}
\hline \multirow{2}{*}{ Metode } & \multicolumn{2}{c}{ Jenis Pengendali (PI) } \\
\cline { 2 - 3 } Tyreus- & $K_{c}$ & $\tau_{i}$ \\
Luyben & $K_{u} / 3,2$ & $2,2 P_{u}$ \\
\hline
\end{tabular}

$$
\begin{aligned}
\text { dengan } K_{u} & =\text { ultimate gain } \\
P_{u} & =\text { ultimate period }
\end{aligned}
$$

\section{Metode Hagglund-Astorm}

Penentuan nilai parameter PI pada metode ini digunakan persamaan seperti ditunjukkan pada Tabel 2 (Haugen, 2010).

Tabel 2. Rumus pengendali PI untuk metode Hagglund-

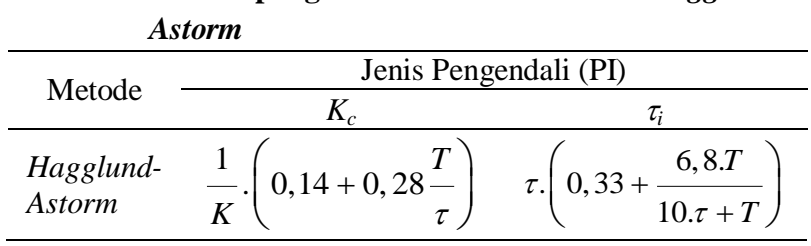

Pada metode ini, nilai $K c$ dan $\tau_{I}$ adalah fungsi $K$ (gain proses), $T$ (konstanta waktu dari proses) dan $\tau$ (waktu tunda dari proses). Pada kedua metode tuning ini, divariasi time delay dari 1 sampai 5 menit. Pada proses orde satu tanpa time delay terdapat kesulitan dalam menentukan ultimate gain $\left(K_{u}\right)$ dan ultimate period $\left(P_{u}\right)$. Sedangkan ditunjukkan pada Tabel 1 , parameter pengendali ditentukan sebagai fungsi $K_{u}$ dan $P u$. Diagram Bode pada proses orde 1 tanpa time delay tidak akan pernah menemukan frekuensi cross over sebab sudut fasanya tidak pernah mencapai $-180^{\circ}$.

Sedangkan pada metode Hagglund-Astorm, cukup jelas ditunjukkan pada Tabel 2 bahwa parameter pengendali adalah fungsi konstantakonstanta untuk proses orde 1 dengan time delay. Hal ini hampir sama dengan metode Cohen Coon yang mempersyaratkan identifikasi proses sebagai proses orde 1 dengan time delay (Coughanowr, 2009).

Untuk mendapatkan ultimate gain $\left(K_{u}\right)$ dan ultimate period $\left(P_{u}\right)$, pertama-tama dibuat diagram Bode untuk sistem lintas terbuka tanpa pengendali. Pada diagram Bode, frekuensi cross over $\left(\omega_{\mathrm{co}}\right)$ ditentukan yaitu pada saat sudut fasa mencapai $-180^{\circ}$. Pada saat frekuensi cross over, harga rasio amplitudo dapat ditentukan, yaitu A, sehingga harga ultimate gain $\left(K_{u}\right)$ dan ultimate period $\left(P_{u}\right)$ adalah dinyatakan dalam Persamaan (15) dan Persamaan (16) (Coughanowr, 2009):

$$
\begin{aligned}
& K_{u}=\frac{1}{A} \\
& P_{u}=\frac{2 \pi}{\omega_{c o}}
\end{aligned}
$$

\section{Hasil dan Pembahasan}

Penurunan model matematis seperti ditunjukkan pada Persamaan 17.

$$
T_{o}(s)=\frac{1}{(\tau \cdot s+1)} T_{i}(s)-\frac{K_{1}}{(\tau \cdot s+1)} Q(s)-\frac{K_{2}}{(\tau \cdot s+1)} W_{S}(s)
$$

Pada Persamaan (17), $Q$ adalah manipulated variable sedangkan $T_{i}$ dan $W_{s}$ adalah gangguan (disturbance). Tabel 3 menunjukkan parameter pada kondisi steady state yang digunakan dalam persamaan model matematis. 
Tabel 3. Parameter saat kondisi steady state

\begin{tabular}{ccc}
\hline Parameter & Harga & Satuan \\
\hline $\mathrm{W}_{\mathrm{s}}$ & 85,6 & $\mathrm{~kg} / \mathrm{menit}$ \\
$\mathrm{M}$ & 2567,5 & $\mathrm{~kg}$ \\
$\mathrm{~T}_{\mathrm{o}, \mathrm{s}}$ & 4 & ${ }^{\circ} \mathrm{C}$ \\
$\mathrm{T}_{\mathrm{i}, \mathrm{s}}$ & 36 & ${ }^{\circ} \mathrm{C}$ \\
\hline
\end{tabular}

Dengan demikian, diperoleh Persamaan (18).

$T_{O}(s)=\frac{1}{(30 \cdot s+1)} T_{i}(s)-\frac{0,002973}{(30 \cdot s+1)} Q(s)+\frac{0,37390}{(30 \cdot s+1)} W_{S}(s)$

Model matematis pada Persamaan 18 disimulasi untuk memperoleh hasil input dan output. Hasil input dan output kemudian diidentifikasi menggunakan System Identification Toolbox (SIT) (Ramdani, 2015) untuk mengetahui kesesuaian model matematis dari penurunan neraca massa dan panas dengan model yang dihasilkan dari SIT. Terdapat 2 perbandingan hasil SIT dengan menggunakan gangguan berupa fungsi transfer orde satu dan sinusoidal. Pertama adalah perbandingan model matematis antara penurunan dengan SIT menggunakan gangguan berupa step disertai dengan fungsi transfer orde 1 .

Tabel 4. Perbandingan model matematis hasil penurunan dengan System Identification Toolbox (gangguan step disertai fungsi transfer orde 1)

\begin{tabular}{|c|c|c|c|}
\hline \multirow{2}{*}{ Metode } & \multicolumn{3}{|c|}{ Fungsi Transfer } \\
\hline & $T_{o}(s) / T_{i}(s)$ & $T_{o}(s) / W(s)$ & $T_{o}(s) / Q(s)$ \\
\hline \multirow{2}{*}{$\begin{array}{c}\text { Penurunan } \\
\text { model matematis }\end{array}$} & 1 & 0,37390 & $-0,002973$ \\
\hline & $(30 \cdot s+1)$ & $(30 \cdot s+1)$ & $(30 \cdot s+1)$ \\
\hline \multirow{2}{*}{ SIT } & 0,978 & 0,36207 & $-0,002868$ \\
\hline & $(29,011 \cdot s+1)$ & $(28,742 \cdot s+1)$ & $(28,524 \cdot s+1)$ \\
\hline
\end{tabular}

Hasil simulasi dari model matematis hasil penurunan dan SIT dengan gangguan berupa fungsi transfer orde 1, naik-turun-naik dengan time constant sebesar 5, 10 dan 7,5 menit pada menit ke-10, 60 dan 110 dapat dilihat pada Gambar 2 dan Gambar 3.

Sedangkan Gambar 4 menunjukkan hasil simulasi dari model matematis hasil penurunan dan SIT dengan gangguan berupa fungsi transfer orde 1 , turun-naik-turun dengan time constant sebesar 12, 6 dan 10 menit pada menit ke-10, 60 dan 110 .
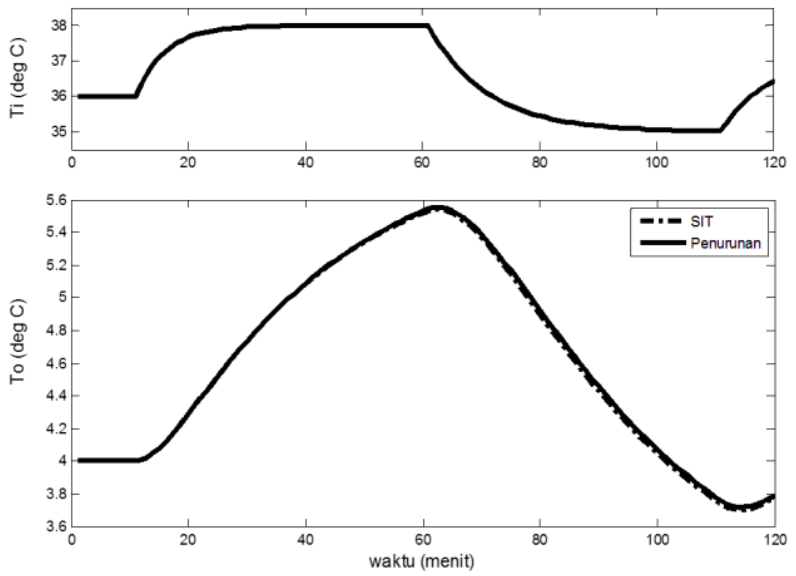

Gambar 2. Perbandingan antara hasil output dari penurunan model matematis dan SIT dengan gangguan $\mathrm{Ti}$ (gangguan berupa fungsi transfer orde 1)
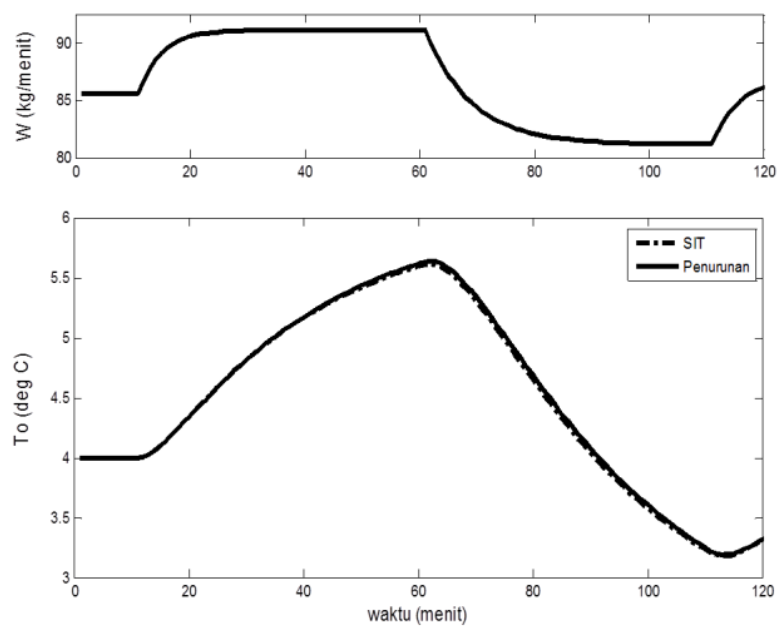

Gambar 3. Perbandingan antara hasil output dari penurunan model matematis dan SIT dengan gangguan $\mathrm{W}$ (gangguan berupa fungsi transfer orde 1 )
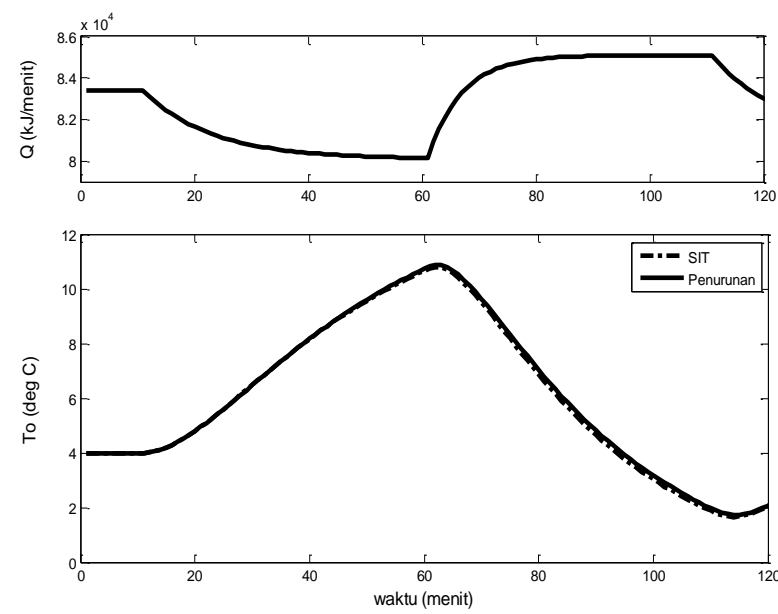

Gambar 4. Perbandingan antara hasil output dari penurunan model matematis dan SIT dengan gangguan $Q$ (gangguan berupa fungsi transfer orde 1) 
Tabel 5. Perbandingan Penurunan Model Matematis dengan Hasil System Identification Toolbox (gangguan sinusoidal

\begin{tabular}{cccc}
\hline \multirow{2}{*}{ Metode } & \multicolumn{3}{c}{ Fungsi Transfer } \\
\cline { 2 - 3 } & $\mathrm{T}_{\mathrm{o}}(\mathrm{s}) / \mathrm{T}_{\mathrm{i}}(\mathrm{s})$ & $\mathrm{T}_{\mathrm{o}}(\mathrm{s}) / \mathrm{W}(\mathrm{s})$ & $\mathrm{T}_{\mathrm{o}}(\mathrm{s}) / \mathrm{Q}(\mathrm{s})$ \\
\hline $\begin{array}{c}\text { Penurunan } \\
\text { model } \\
\text { matematis }\end{array}$ & $\frac{1}{(30 \cdot \mathrm{s}+1)}$ & $\frac{0,37390}{(30 \cdot \mathrm{s}+1)}$ & $\frac{-0,002973}{(30 \cdot \mathrm{s}+1)}$ \\
SIT & $\frac{0,92152}{(27,205 \cdot \mathrm{s}+1)}$ & $\frac{0,34456}{(27,205 \cdot \mathrm{s}+1)}$ & $\frac{-0,0027397}{(27.205 \cdot \mathrm{s}+1)}$ \\
\hline
\end{tabular}

Selanjutnya model matematis divalidasi dengan menggunakan dinamik data set yang berbeda yaitu dengan menggunakan gangguan berupa data input sinusoidal. Hasil simulasi dari model matematis hasil penurunan dan SIT dengan gangguan berupa fungsi sinusoidal terdapat pada Gambar 5 hingga Gambar 7.
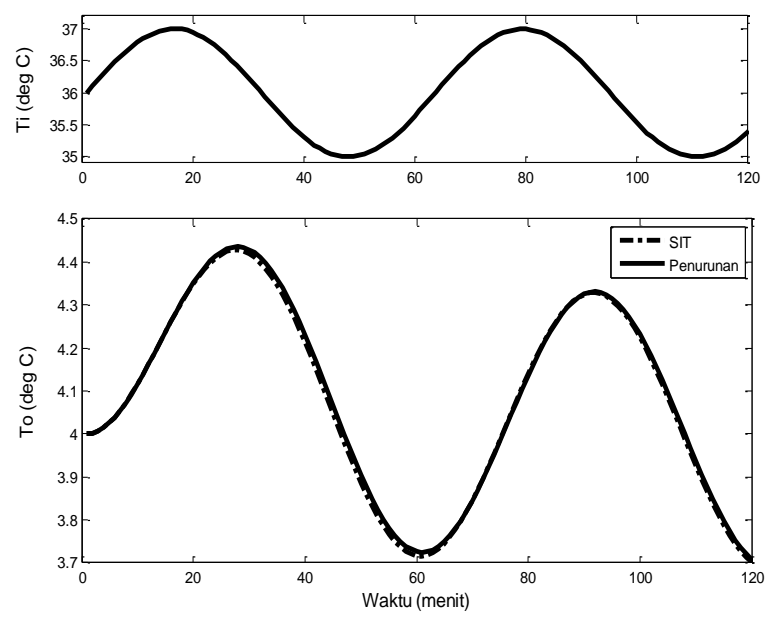

Gambar 5. Perbandingan antara hasil output dari penurunan model matematis dan SIT dengan gangguan Ti (gangguan sinusoidal)

Dari tabel serta grafik perbandingan antara hasil output dari penurunan model matematis dan SIT di atas, baik dengan gangguan berupa fungsi step disertai dengan fungsi transfer orde 1 maupun sinusoidal, ditunjukkan bahwa hasil penurunan model matematis mendekati dengan hasil dari SIT. Hal ini disebabkan oleh besarnya incremental data yang digunakan, yaiitu sebesar 1 menit. Hasil yang lebih teliti akan diperoleh bila incremental data yang dipilih dan dianalisa, dibuat lebih kecil lagi. Model matematis hasil SIT dengan gangguan berupa fungsi step disertai dengan fungsi transfer orde 1 , selanjutnya digunakan untuk penyetelan pengendali karena hasilnya yang paling mendekati hasil penurunan. Sebelum dilakukan penyetelan pengendali, sistem ini dirancang menjadi sistem lintas tertutup (close loop).

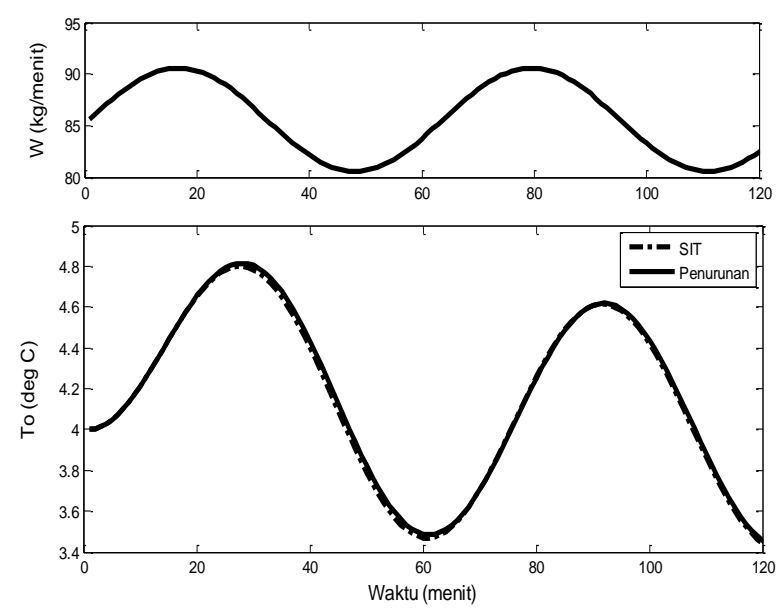

Gambar 6. Perbandingan antara hasil output dari penurunan model matematis dan SIT dengan gangguan W (gangguan sinusoidal)

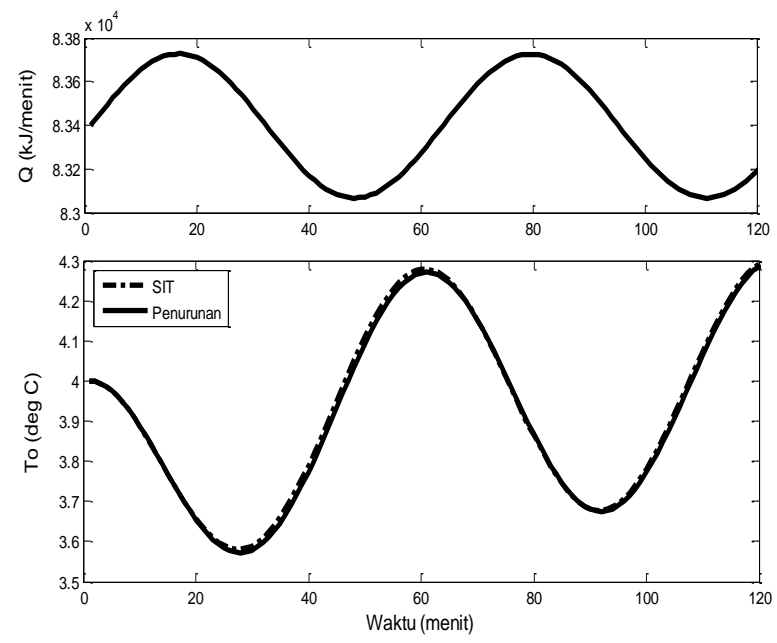

Gambar 7. Perbandingan antara hasil output dari penurunan model matematis dan SIT dengan gangguan Q (gangguan sinusoidal)

Jenis pengendali yang digunakan adalah Proportional-Integral (PI). Untuk mencari nilai parameter PI yaitu $K_{c}$ dan $\tau_{i}$ adalah dengan menggunakan metode Tyreus-Luyben dan Hagglund-Astorm. Untuk kedua metode ini dibutuhkan asumsi time delay ( $\theta$ ) (Agustriyanto, 2018). Variasi time delay yang digunakan adalah 1 sampai 5 menit. Variasi time delay ini digunakan untuk mengetahui time delay mana yang menghasilkan error antara set point terhadap output yang terkecil untuk sistem ini. 
Persamaan 19 dan Gambar 8 adalah bentuk fungsi transfer dengan asumsi time delay:

$$
\frac{T_{O}(s)}{Q(s)}=-\frac{K_{1}}{(\tau \cdot s+1)} \cdot e^{-\theta s}
$$

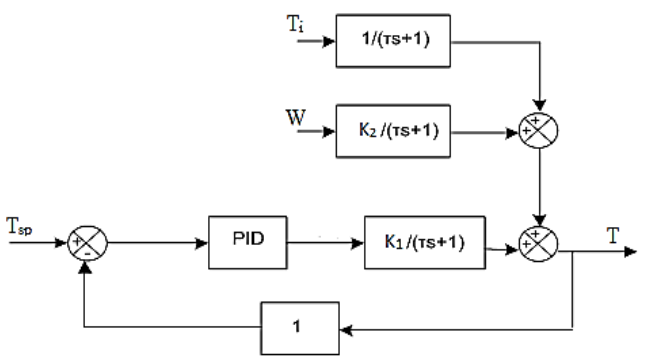

Gambar 8. Diagram simulasi sistem pendinginan susu kontinu

Penyetelan menggunakan metode TyreusLuyben

Pada metode ini, untuk menghitung nilai $\mathrm{K}_{\mathrm{c}}$ dan $\tau_{\mathrm{i}}$ digunakan diagram Bode. Persamaan 20 dan Gambar 9 adalah contoh perhitungan dengan asumsi $\theta=1$ :

$$
\frac{T_{O}(s)}{Q(s)}=-\frac{0,002868}{(28,524 \cdot s+1)} \cdot e^{-1 s}
$$
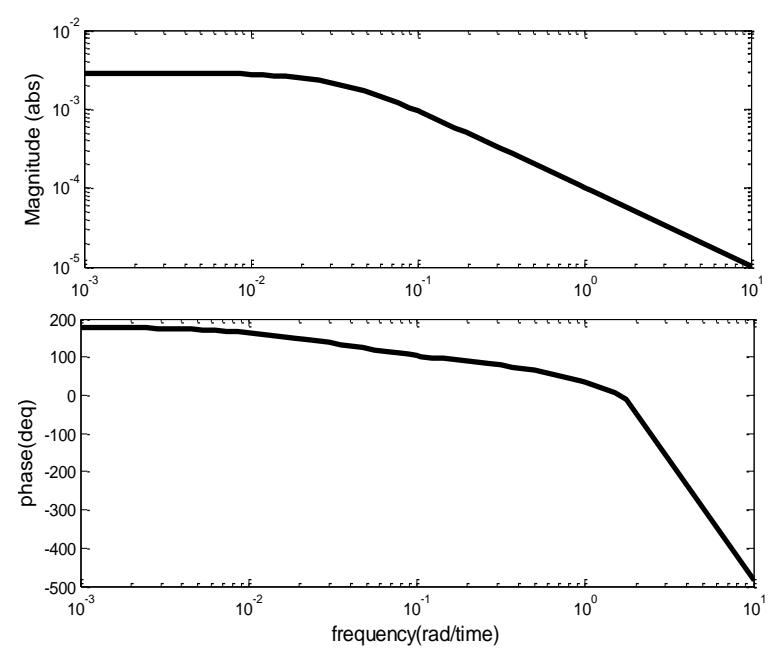

Gambar 9. Diagram Bode

Diagram Bode menunjukkan nilai frekuensi cross-over sebesar 3,283 rad/time dan magnitude (abs) sebesar $3,061 \times 10^{-5}$ abs. Dari nilai tersebut, nilai ultimate gain $\left(K_{u}\right)$ dan ultimate period $\left(P_{u}\right)$ dapat ditentukan.

$$
\begin{aligned}
& K_{u}=32669,0624 \\
& P_{u}=1,9129
\end{aligned}
$$

Harga parameter pengendali ditunjukkan pada Tabel 6 dengan berbagai asumsi time delay yang dihitung sesuai dengan rumus pada Tabel 1.

Tabel 6. Harga parameter pengendali Tyreus-Luyben

\begin{tabular}{ccc}
\hline Time delay & $K c$ & $\tau_{i}$ \\
\hline 1 & $-10209,0820$ & 4,2083 \\
2 & $-6200,3968$ & 6,9253 \\
3 & $-4893,5171$ & 8,7776 \\
4 & $-3674,3092$ & 11,6887 \\
5 & $-2953,6862$ & 14,5508 \\
\hline
\end{tabular}

Berikut adalah profil set point dan output dengan berbagai asumsi time delay:

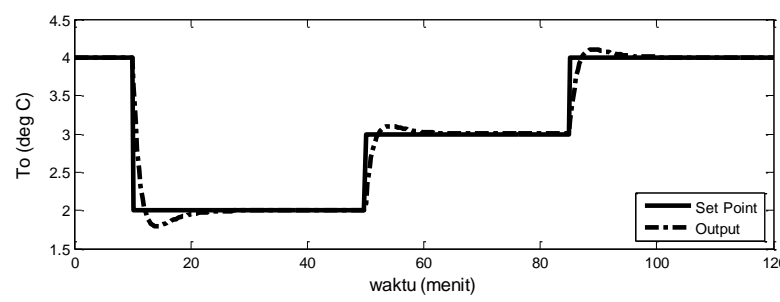

Gambar 10. Profil output dan set point dengan asumsi time delay = 1 menggunakan metode TyreusLuyben

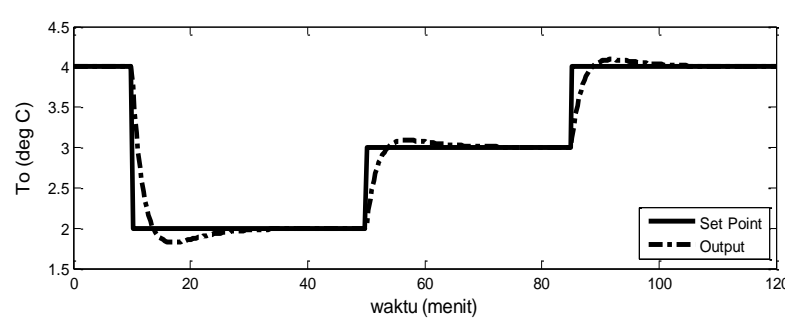

Gambar 11. Profil output dan set point dengan asumsi time delay $=2$ menggunakan metode TyreusLuyben

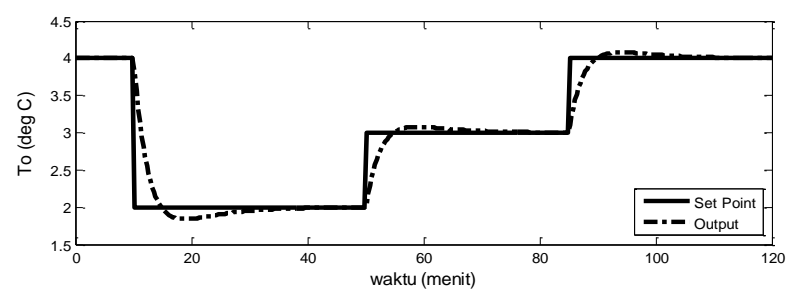

Gambar 12. Profil output dan set point dengan asumsi time delay = 3 menggunakan metode TyreusLuyben

Dengan adanya time delay maka waktu proses akan tertunda. Berdasarkan Gambar 10-14 dapat dilihat bahwa semakin besar asumsi time delay maka profil output akan semakin menjauhi set point. 


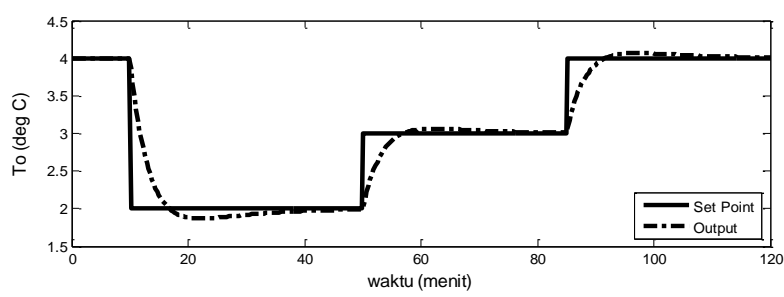

Gambar 13. Profil output dan set point dengan asumsi time delay $=4$ menggunakan metode TyreusLuyben

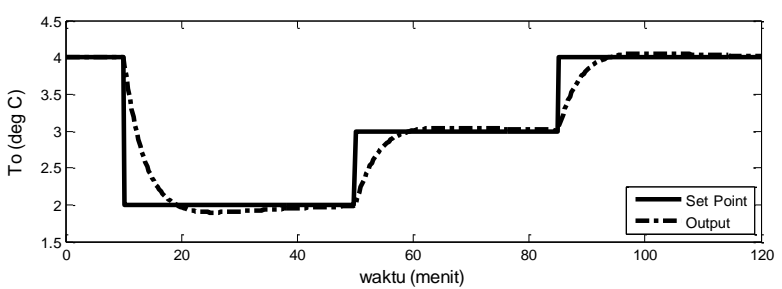

Gambar 14. Profil output dan set point dengan asumsi time delay $=5$ menggunakan metode TyreusLuyben

Penyetelan menggunakan metode HagglundAstorm

Pada metode ini, untuk memperoleh harga $K_{c}$ dan $\tau_{i}$, harga $K_{l}$, $\tau$, dan $\theta$ yang terdapat pada fungsi transfer langsung dimasukkan pada persamaan yang terdapat pada Tabel 2 sehingga diperoleh harga parameter pengendali dengan berbagai asumsi time delay pada Tabel 7.

Tabel 7. Harga parameter pengendali Hagglund-Astorm

\begin{tabular}{ccc}
\hline Time delay & $\mathrm{Kc}$ & $\tau_{\mathrm{i}}$ \\
\hline 1 & $-2833,7820$ & 5,3649 \\
2 & $-1441,3000$ & 8,6545 \\
3 & $-977,1393$ & 10,9328 \\
4 & $-745,0589$ & 12,6424 \\
5 & $-605,8107$ & 14,0006 \\
\hline
\end{tabular}

Gambar 15-19 menunjukkan profil set point dan output dengan berbagai asumsi time delay.

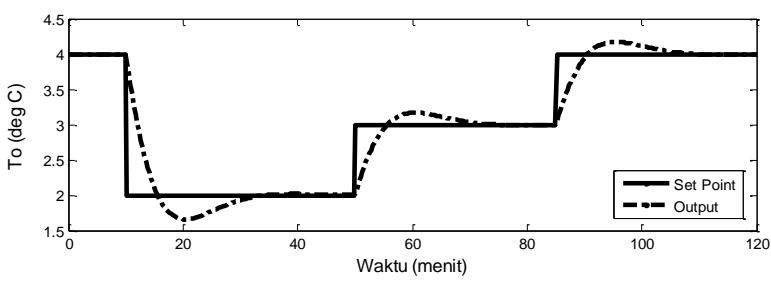

Gambar 15. Profil output dan set point dengan asumsi time delay $=1$ menggunakan metode Hagglund-Astorm

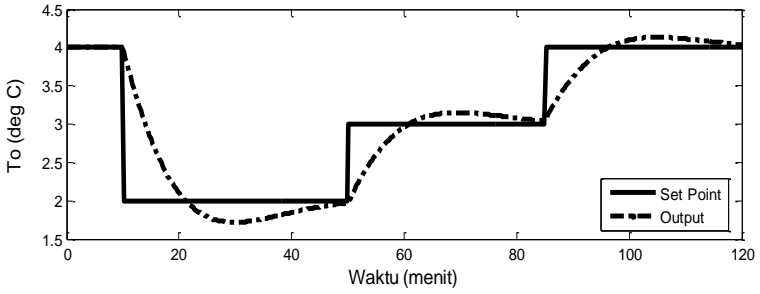

Gambar 16. Profil output dan set point dengan asumsi time delay $=2$ menggunakan metode Hagglund-Astorm

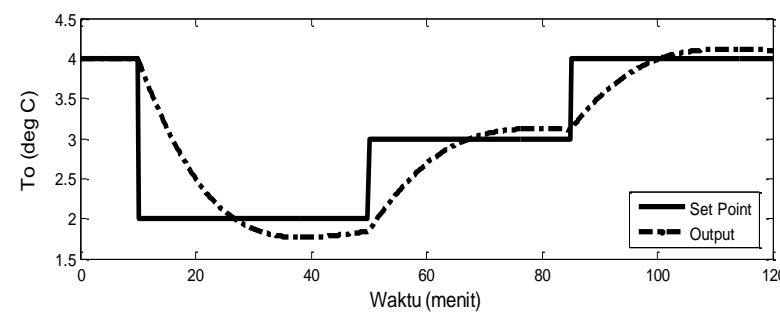

Gambar 17. Profil output dan set point dengan asumsi time delay $=3$ menggunakan metode Hagglund-Astorm

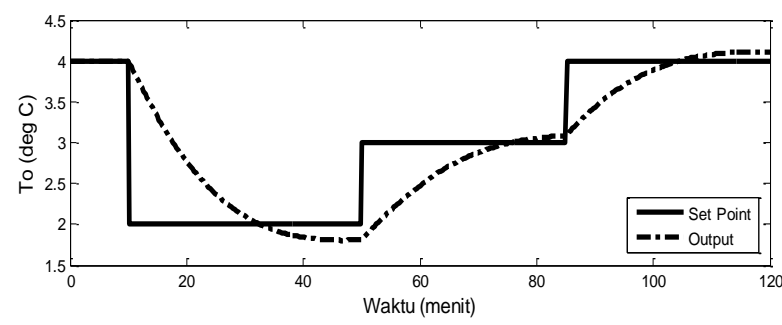

Gambar 18. Profil output dan set point dengan asumsi time delay $=4$ menggunakan metode Hagglund-Astorm

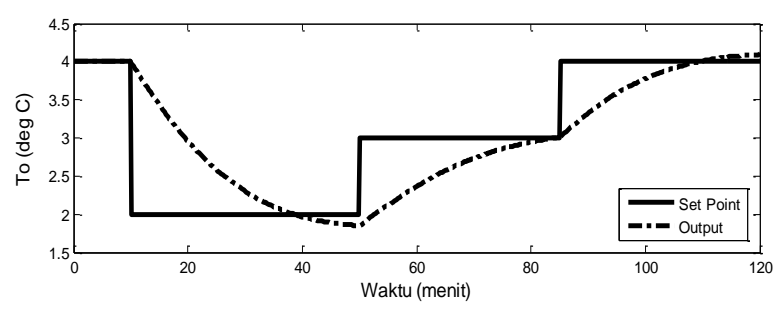

Gambar 19. Profil output dan set point dengan asumsi time delay $=5$ menggunakan metode Hagglund-Astorm

Berdasarkan Gambar 15-19, semakin besar asumsi time delay maka profil output akan semakin menjauhi set point. Berikut adalah perbandingan hasil uji SSE (Sum of Square Error) antara metode Tyreus-Luyben dan Hagglund-Astorm: 
Tabel 8. Harga uji SSE

\begin{tabular}{ccc}
\hline \multirow{2}{*}{ Time delay } & \multicolumn{2}{c}{ SSE } \\
\cline { 2 - 3 } & Tyreus-Luyben & Hagglund-Astorm \\
\hline 1 & 6,8160 & 12,8880 \\
2 & 8,2288 & 20,9121 \\
3 & 9,3019 & 28,9754 \\
4 & 11,0796 & 37,1813 \\
5 & 12,9081 & 45,3328 \\
\hline
\end{tabular}

Dari kedua metode di atas, metode TyreusLuyben lebih dipilih karena nilai error-nya lebih kecil bila dibandingkan dengan metode Hagglund-Astorm. Maka untuk sistem pendinginan susu secara kontinu ini, metode pengendali yang paling sesuai digunakan adalah metode Tyreus-Luyben. Namun demikian, investigasi lebih lanjut perlu dilakukan, khususnya untuk kasus disturbance rejection, sebab data di atas adalah untuk setpoint tracking. Hal ini disebabkan karena umumnya harga setpoint adalah tetap untuk kasus pendinginan susu. Perubahan set point dalam hal ini jarang dilakukan.

Dari aspek kemudahan dalam melakukan penyetelan (tuning), tampak bahwa metode Hagglund-Astorm lebih mudah dilakukan dibandingkan metode Tyreus-Luyben. Metode Tyreus-Luyben lebih rumit karena membutuhkan analisis respon frekuensi dengan membuat diagram Bode terlebih dahulu.

\section{Kesimpulan}

Hasil yang diperoleh menunjukkan bahwa kinerja pengendali yang disetel menggunakan metode Tyreus-Luyben lebih baik dibandingkan dengan metode Hagglund-Astorm. Hal ini ditunjukkan dengan nilai SSE yang jauh lebih kecil (pada semua asumsi time delay). Saran dari penelitian ini adalah perlu dilakukan identifikasi dengan metode lain yang ada pada System Identification Toolbox untuk memperoleh model matematis, serta perlu dicoba metode pengendali lainnya.

\section{Ucapan Terima Kasih}

Penulis mengucapkan terimakasih kepada Universitas Surabaya yang telah mendukung penelitian ini.

\section{Daftar Pustaka}

Agustriyanto, R., 2018, kendali sistem bioreaktor kontinu, Jurnal Teknik Kimia USU, 7, 1-4.

Coughanowr, D.R., LeBlanc, S.E., 2009, Process Systems Analysis and Control, $3^{\text {rd }}$ ed, McGraw-Hill's, New York.

Haugen, Finn, 2010, Comparing PI tuning methods in a real benchmark temperature control system, Model., Identif. Control, 31, 79-91.

Murphy, Michael D. Upton, John. O’Mahony, Michael J., 2012, Rapid milk cooling control with varying water and energy consumption, Bioprocess. Eng., 116, 15-22.

Ramdani, Evan, 2015, Parameter identifikasi transfer fungsi menggunakan MATLAB, Setrum, 4, 1-7.

Ruangwuttayanusorn, Khanitta. Promket, Doungnapa. Ahantiratikul, Anut, 2016, Monitoring the hygiene of raw milk from farms to milk retailers, Agriculuture and Agricultural Science Procedia, 11, pp. 95-99.

Shahrokhi, M., Zomorrodi, A., 2018, Comparasion of PID Controller Tuning Methods, Department of Chemical \& Petroleum Engineering, Sharif University of Technology

Sheng Pai, Neng. Chichang, Shih. Tsung Huang, Chi, 2009, Tuning PI/PID controllers for integrating processes with deadtime and inverse response by simple calculation, Journals of Process Control, 20, 726-723.

Suwito, Widodo, 2009, Bakteri yang Sering Mencemari Susu: Deteksi, Patogenesis, Epidemiologi, dan Cara Pengendaliannya, Balai Pengkajian Teknologi Pertanian Yogyakarta, 96-100.

Toledo, Victor Toires. Meissnes, Klaus. Coronas, Alberto. Mulles, Joachim, 2015, Performance characterisation of a small milk cooling system with ice storage for PV applications, Int. J. Refrig., 60, 81-91. 